\title{
Lutar com palavras entre ruínas: narrativa e errância em Flores artificiais, de Luiz Ruffato
}

\author{
Marcela Ferreira Silva*
}

\begin{abstract}
Resumo
A narrativa brasileira contemporânea tem problematizado a relação do sujeito com o espaço de diferentes maneiras, com destaque para a tematização do trânsito nos grandes centros urbanos e as inúmeras viagens realizadas pelas personagens. Esses "não lugares" (AUGÉ, 1994) têm sua relevância garantida por meio da construção de personagens transeuntes, andarilhos, viajantes, turistas, migrantes e imigrantes, que não conseguem se fixar em lugar nenhum, tampouco estabelecer relações de intimidade e pertencimento com os espaços por onde transitam. À luz dessas constatações, discutiremos o entrelaçamento dos temas da errância e da narrativa no romance Flores artificiais, de Luiz Ruffato, publicado em 2014, visto que, nesse romance, além da referida problematização do sujeito com os espaços, questionam-se, também, as fronteiras da narrativa no contexto da contemporaneidade.
\end{abstract}

Palavras-chave: Testemunha. Viagem. Narrativa.

Recebido em: 26/03/2017

Aceito em: 17/05/2017

* Universidade Federal de Goiás (UFG/FAPEG). Mestre em Letras e Linguística pela Universidade Federal de Goiás e doutoranda em Letras pela mesma Universidade. 


\section{Considerações iniciais}

[...] a vida pode ser inverossímil, a arte não. (RUFFATO, 2014, p. 12).

Em É isto um homem?, Primo Levi (1988) relata um terrível sonho que atormentava os prisioneiros dentro do Lager. Depois de sobreviver, eles voltavam para casa e narravam aos outros os horrores que sofreram nos campos de extermínio, no entanto, os ouvintes levantavam e iam embora, recusando-se a ouvir a história dos sobreviventes. Analisando esse sonho de Levi, Jeanne Marie Gagnebin (2009) chama a atenção para um novo tipo de testemunha que precisa ser evocado na contemporaneidade, a fim de que a memória de tristes fenômenos, como a memória da Shoah, não caia no esquecimento. Para além do par mortífero vítima-algoz, a terceira forma de testemunha seria aquela que não vai embora, que fica e ouve o relato do sobrevivente.

Testemunha também seria aquele que não vai embora, que consegue ouvir a narração insuportável do outro e que aceita que suas palavras levem adiante, como num revezamento, a história do outro: não por culpabilidade ou por compaixão, mas porque somente a transmissão simbólica, assumida apesar e por causa do sofrimento indizível, somente essa retomada reflexiva do passado pode nos ajudar a não repeti-lo infinitamente, mas a ousar esboçar uma outra história, a inventar o presente. (GAGNEBIN, 2009, p. 57).

É esse tipo de testemunha que Luiz Ruffato explora como narrador no romance Flores artificiais, publicado em 2014. Essa narrativa resulta de uma coletânea de memórias narradas pela personagem Dório Finetto, quando ele visita diferentes cidades do planeta, enquanto engenheiro consultor do Banco Mundial. Nessas viagens, o narrador encontra pessoas que lhe contam suas histórias e ele se prontifica a ouvi-las. O romance nasce dessas experiências de ouvinte. A narrativa sugere um texto autobiográfico, mas a história de si vai se tornando rarefeita para dar lugar à história do outro, aquelas personagens que Dório encontra nos lugares por onde passa.

A partir da publicação de Eles eram muitos cavalos em 2001, Ruffato tem se destacado no cenário da literatura contemporânea. Essa relevância do escritor para as letras nacionais pode ser mensurada pela quantidade de teses, dissertações, 
ensaios e livros sobre a obra do autor publicados nos últimos anos. Um exemplo disso é o livro Uma cidade em camadas: ensaios sobre o romance Eles eram muitos cavalos, de Luiz Ruffato, organizado nos Estados Unidos por Marguerite Itamar Harrison. O livro reúne textos de críticos no Brasil e no exterior, a exemplo de Andrea Saad Hossne, Carmen Villarino Pardo e Renato Cordeiro Gomes (HARRISON, 2007). Essa importância do escritor para os estudos literários é reiterada por Regina Dalcastagnè (2007), ao apresentar o referido livro: “As variadas leituras suscitadas pelo romance [...] sinalizam a riqueza da obra de Luiz Ruffato, ao mesmo tempo em que apontam a fecundidade da crítica sobre a literatura do Brasil de hoje". Além dessa recepção crítica, o autor tem publicado inúmeras obras, organizado outras, ganhado prêmios, e muitos de seus romances foram traduzidos em vários países, como Alemanha, Finlândia, Portugal, França, Itália, Argentina, Colômbia, México, Cuba e Estados Unidos.

No último capítulo de Flores artificiais, o narrador-personagem esbarra com um norte-americano na baía do porto de San Juan Antiguo, em Porto Rico. A elaboração desse episódio pela memória do narrador é reconstituída de forma significativa para interpretar os sentidos de dois aspectos importantes desse romance: a narração e a errância. $\mathrm{O}$ trecho que relata esse encontro, transcrito em seguida, será importante para interpretar o texto literário ruffatiano e merece atenção por sintetizar os questionamentos que este trabalho se propõe a responder: quais os sentidos da arte de narrar no contexto da contemporaneidade, em que a experiência se tornou incomunicável? Quais os significados da errância e dos constantes deslocamentos nessa narrativa de viagens?

A luz da manhã cingia a magnífica baía de San Juan Antiguo naquele sábado de maio. Impelido pela excitação da primavera, caminhava distraído rumo às estreitas vielas de San Juan Antiguo. [...] Estava parado, de pé, observando o movimento, quando percebi, vindo em minha direção, um americano típico, tênis, meias três-quartos, bermuda jeans, camisa florida aberta que deixava à mostra os cabelos brancos do peito e o cordão de ouro, boné azul do Texas Rangers. Ele disse algo, no peculiar sotaque sulista, que não alcancei mas que me pareceu amistoso. Respondi saudando-o com um meneio de cabeça, que ele de pronto correspondeu, aproximando-se e apertando-me a mão. Era um homem com seus sessenta e poucos anos, ótima forma física, devia praticar esportes. Disse seu nome, que não entendi, falei o meu, que custou a compreender. Perguntou para onde ia, Vamos na mesma direção, estou naquele navio lá, e apontou para um dos três ou quatro imensos transatlânticos 
ancorados no cais. Em seguida, indagou o que fazia em Porto Rico, e, quando expliquei que participava de um congresso, mirou-me com certo descaso, Sou aposentado, minha profissão é viajar. Você de onde é? Respondi, e ele emendou, Conheço seu país, Conheço São Paulo, Rio de Janeiro, Bahia, Fortaleza, Amazonas. Estive por lá cinco vezes. E gostou? Tirou o boné, e notei que cultivava certo embaraço por sua cabeça inteiramente nua, passou a mão na careca para limpar o suor, Muito boa a caipirinha... Mas não achei no Brasil o que venho buscando... Não será o Brasil o meu destino final... [...] Sou veterano do Vietnã, e em La Drang imaginei que fosse sucumbir, como milhares de compatriotas, então pensei que se saísse ileso daquele lugar eu dedicaria o resto do meu tempo a não fazer nada, apenas vagaria de um canto a outro, descobrindo paisagens e articulando amizades, porque as ilusões, meu amigo, essas abandonei nos campos de batalha, atoladas naquela mortandade inútil e sem sentido. Não sei quem me protegeu, se Deus ou Diabo, mas em 1970 lembraram de mim, espetaram medalhas no meu uniforme e me devolveram para casa. Desde então já percorri todos os Estados Unidos, o Canadá, o México, a América Central e a do Sul, menos as tais Guianas, e agora estou investigando o Caribe... Porque decidi que só vou morrer depois que descobrir uma paragem aprazível para ser enterrado, um cemitério bonito, com uma vista estupenda, num lugar seco, porque não gosto de umidade, mas que não seja o deserto, de temperatura constante, porque não gosto de frio excessivo nem de calor excessivo... Enquanto não me deparo com esse lugar, vou adiando a morte... Deteve-se em frente ao Splendour of the Seas, apertou minha mão, Fico aqui, prazer em conhecê-lo. (RUFFATO, 2014, p. 138-140).

Primeiramente, nota-se que essa personagem que Dório encontra em Porto Rico serve de emblema para se pensar a relação conflituosa do sujeito com os lugares, acentuada nas últimas décadas do século XX. Um ex-combatente de guerra no Vietnã, ao voltar para casa, não consegue mais pertencer a esse espaço e viaja compulsoriamente, resistindo à fixação e a tudo que estabelecer raízes implica. $\mathrm{O}$ motivo que o impulsiona à errância advém do desejo de encontrar uma "paragem aprazível para ser enterrado", porque os Estados Unidos já não representam mais o lar ou a "pátria retórica". O lugar onde se deseja ser enterrado é significativo para ele, porque ser enterrado pressupõe integrar-se ao espaço e, mais que isso, tratase de uma integração definitiva por meio da morte. Por isso, toda relação com o espaço é subjetiva, não está associada apenas aos limites físico-geográficos, mas diz respeito também à retórica de sociabilidade que o lugar engendra e compartilha com seus habitantes. 
O segundo ponto importante constitui-se na busca pelo outro lugar, movida pela expectativa do que virá. Novamente, o lugar que se espera encontrar é projetado a partir de anseios subjetivos, um lugar ameno, de clima e sociabilidade amenos e sem conflitos. Não encontrando esse lugar, o sujeito se torna um errante: "Mas não achei no Brasil o que venho buscando... Não será o Brasil o meu destino final." (RUFFATO, 2014, p. 139). Dessa forma, a errância se constitui como a possibilidade da existência em um mundo eivado pela guerra. Ela ocorre em virtude da descrença que permeia a retórica que o lugar faz erigir: "Porque as ilusões, meu amigo, essas abandonei nos campos de batalha, atoladas naquela mortandade inútil e sem sentido." (RUFFATO, 2014, p. 139).

Assim como a errância será uma constante em todos os capítulos de Flores artificiais, há também essa capacidade de Dório para ouvir a história daqueles que ele encontra em suas viagens e, por conseguinte, a disposição para narrá-las, ou seja, dessa experiência de encontros efêmeros surge algo que vale a pena não deixar cair no esquecimento, que são as histórias desses seres anônimos. Dório Finetto é a testemunha que não vai embora. Ao vagar por diversos países nas últimas décadas do século XX, ele encontra pessoas de diferentes lugares do mundo, e todas elas, de uma forma ou de outra, foram atormentadas pelo trauma, individual ou coletivo, que as tornou seres errantes e em permanente conflito com os lugares.

Dório reconta sua história em um livro como resultado, também, da tentativa de vencer um trauma pessoal. A errância assim como a narrativa são modos de resistir e continuar dando sentido à existência em um mundo sem utopias e em ruínas, sendo, para tanto, necessário um narrador que explora essas ruínas e retira delas o indizível e o inenarrável.

Alinhavados os pressupostos interpretativos que dão lastro às questões referentes à errância e à narrativa no texto Flores artificiais, de Luiz Ruffato (2014), este trabalho se organiza em torno de dois tópicos. No primeiro, pretendese observar como são construídos os significados da arte narrativa tanto para Dório quanto para o projeto literário do escritor Ruffato, "autoficcionalizado" no romance, num momento em que, como afirma Walter Benjamin (1987), decretouse o fim da arte de narrar. No segundo tópico, propõe-se analisar os sentidos da errância do narrador-personagem, que faz dele um tecedor de ruínas, um narrador que coleta suas experiências em um mundo caótico, caracterizado pela violência, pela catástrofe e pela dor. 


\section{Realidade e ficção: lutar com as palavras entre ruínas}

O romance Flores artificiais problematiza as fronteiras do real e do fictício ao inserir o próprio Luiz Ruffato como uma das personagens. Dório Finetto, conterrâneo e contraparente de Ruffato, elabora alguns relatos de suas viagens pelo mundo como consultor do Banco Mundial, intitulados Viagens à terra alheia, e envia-os à personagem do escritor, que reelabora essas experiências de Dório e nos apresenta como resultado o romance Flores artificiais.

Dessa forma, o romance é um "livro dentro do livro" e organiza-se em duas partes. No conjunto, verificam-se Flores artificiais: composto por uma apresentação inicial, na qual Ruffato-personagem trata de seu projeto literário, da experiência de receber os relatos de Dório e da organização do romance. $\mathrm{Na}$ sequência, insere-se a carta de Dório, na qual ele expõe os motivos que o levaram a escrever os relatos de Viagens à terra alheia, concedendo plenos direitos a Ruffato sobre as histórias: "Dou inteira liberdade para o que decidir. Até mesmo para simplesmente jogar tudo no lixo.” (RUFFATO, 2014, p. 14). Após a carta é que se iniciam os relatos de Dório, e após essas narrativas, incorpora-se um memorial descritivo, em que Ruffato esclarece detalhes sobre a vida de Dório e no qual ele afirma não se reconhecer.

Viagens à terra alheia é composto por oito histórias: a primeira conta a história de Bobby e se passa no Brasil, quando Dório vive em Juiz de Fora e estuda engenharia; a segunda se passa em Buenos Aires, Argentina: Dório conhece uma francesa que busca um novo sentido para a vida em outro país; a terceira se passa em Dolores, Uruguai: Dório conhece um citadino chamado El Gordo, cuja infância fora marcada pela repressão da ditadura em seu país; a quarta se passa em Havana, Cuba: Dório conhece Nádia, uma mulher desesperada para fugir da miséria e da violência que permeiam essa sociedade assolada pela repressão; a quinta se passa em Hamburgo, Alemanha: Dório conhece Anka, uma mulher solitária, dona da pensão onde ele fica hospedado; a sexta se passa em Beirute, Líbano: Dório conhece Marcelo, um argentino que também viaja pelo mundo porque já não tem um lugar ao qual pertencer; a sétima se passa em Díli, Timor Leste: Dório conhece Alexandre, cuja vida fora marcada pela miséria, pela violência e pela dor da perda; a oitava se divide em duas partes, o referido encontro com o norte-americano em Porto Rico, e, no Brasil, Dório está em seu apartamento, sozinho, na virada do milênio, acometido por uma grave depressão, sendo encontrado e encaminhado ao hospital. 
Feita essa descrição geral da estrutura do romance, observa-se que, nessas partes que antecedem os relatos de Viagens à terra alheia, a narrativa é questionada em duas instâncias. Primeiramente, impõe-se à leitura do romance averiguar as fronteiras entre vida e ficção para o projeto literário de Ruffato, ficcionalizado como uma das personagens do sistema interno da obra. Trata-se de uma estratégia narrativa muito comum nos romances realistas: aproximar obra e realidade servia, como afirma Jack Goody (2009), para dar maior credibilidade à literatura, como conhecimento privilegiado do real, já que o estatuto de ficcionalidade era tratado como um aspecto negativo naquele momento.

No entanto, na contemporaneidade, bem depois de a arte reivindicar a sua autonomia, há uma ressignificação do que se configura como literário, e o termo sugerido pelos estudiosos da segunda metade do século XX para esse embaralhamento das fronteiras entre ficção e realidade é a autoficção. Trata-se da ficcionalização do escritor, pessoa com registro civil inserida no âmbito da ficção, tornando-se personagem da narrativa, numa mistura de autobiografia e romance. Segundo a perspectiva de Kelley Duarte, essa característica deixa entrever o papel da literatura, na contemporaneidade, de constituir-se como

[...] um espaço de restituição e recomposição dos resquícios do vivido, da memória, em um período pós-guerra ou pós-trauma, a nova escritura do eu que emerge ganha dimensões terapêuticas de uma escrita reparadora, dando conta de um sujeito fragmentado e de uma nova percepção de si mesmo. (DUARTE, 2010, p. 27).

Nas primeiras décadas do século XXI, essa estratégia também pode ser interpretada como resistência à morte da narrativa, decretada por um contingente significativo de estudos críticos do século XX. Quem primeiro alertou para o fim da arte de narrar foi Walter Benjamin (1987), nos idos de 1935-1936, em um texto intitulado "O narrador: considerações sobre a obra de Nikolai Leskov". Para alcançar as proposições de Walter Benjamin nesse texto, talvez, seja necessário compreender antes o contexto em que ele o escreveu. Trata-se de um ensaio de 1936, quatro anos antes de sua morte, momento em que Benjamin, alemão de origem judia, já pressentia o seu não lugar tanto na academia conservadora quanto na Alemanha nazista. Desde 1933, Hitler já havia se tornado o chanceler do Reich e empreendido uma "caça aos judeus" não só da Alemanha como de outros países. Noutras palavras, Benjamin escreve em um período tenso entre guerras. Apesar 
de ter se suicidado em 1940 e não ter vivido até o desfecho da Segunda Grande Guerra, já sentia as suas consequências: suicida-se na fronteira entre a França e a Espanha, tentando fugir da perseguição nazista. Segundo Gagnebin (2009), se Benjamin não tivesse cometido suicídio, teria morrido nos campos de extermínio.

Feita essa alusão contextual, talvez se torne mais compreensível a tese de Benjamin (1987, p. 197) nesse texto, ao afirmar a morte da narrativa: "É a experiência de que a arte de narrar está em vias de extinção. São cada vez mais raras as pessoas que sabem narrar devidamente." Na concepção do autor, os soldados sobreviventes voltavam da guerra mais pobres em experiências comunicáveis, porque a guerra é desmoralizante e a arte de narrar se associa com a transmissão de uma experiência edificante, em que aquele que narra tem um ensinamento a ser transmitido.

Essa afinidade de Dório com a arte da narrativa remete a essas considerações de Benjamin (1987) sobre a morte da arte de narrar na contemporaneidade. Para Benjamin (1987, p. 198), não há mais experiências comunicáveis. A sua tese é a de que: "No final da guerra, observou-se que os combatentes voltavam mudos do campo de batalha não mais ricos, e sim mais pobres em experiência comunicável." Nesse sentido, é possível observar que o norte-americano que Dório encontra é um combatente que voltou da guerra e a experiência que ele tem a comunicar é a experiência das ruínas, os traumas de um mundo caótico e bárbaro que não acolhe os sujeitos, mas que os expulsa e os segrega, restando-lhes a errância como resistência e como recuperação do vestígio de humanidade que a hostilidade do mundo thes tolheu. $\mathrm{O}$ ex-combatente vaga para encontrar um lugar melhor, para simbolizar as ruínas que a guerra legou, para vencer o trauma.

O papel do escritor contemporâneo se confunde com o do narrador (RuffatoDório), ambos são incapazes de simbolizar a experiência da guerra e do trauma. Entretanto, eles se traduzem na figura da testemunha que não vai embora, que escuta o indizível, o insuportável relato do sobrevivente para, depois, como num revezamento, transformar em literatura, a qual não consiste na transcrição do real, mas na sua representação. Tanto Dório, a testemunha que escuta o relato de outras personagens traumatizadas e narra-o para vencer seu próprio trauma individual, quanto Ruffato, personagem do escritor que se debruça sobre os relatos de Dório, são as respostas formais que a literatura consegue dar a esses questionamentos contemporâneos. 
Em certa altura de seu texto, Benjamin (1987, p. 198) afirma que: "A arte de narrar está definhando porque a sabedoria — o lado épico da verdade — está em extinção." Se pensarmos no contexto de Benjamin, período entre guerras, de tensões políticas, de perseguições e, também, de conservadorismo da academia, é possível compreender que não existem mais sabedoria e experiência comunicáveis nesse mundo. Que conselhos podem ser dados quando o mundo acabou de sair de uma guerra e já começa a empreender outra? Não há experiência comunicável, compartilhamento de sabedoria em um mundo de guerras, barbáries e horrores. Guerra feita por homens contra homens. Se o conselho tem a característica de obter um conhecimento, a fim de advertir sobre os erros e, por conseguinte, aprender com eles e evitá-los, o contexto de Benjamin mostra bem o contrário: não há sabedoria na guerra. A crise da narrativa é, por extensão, a crise da ciência, do saber, da religião e de muitas outras verdades iluministas que fundaram o mundo moderno.

Longe de querer afirmar o contrário de Benjamin (1987), que a experiência na contemporaneidade é plena, Ruffato parece traçar uma terceira via para o problema da narrativa literária, reivindicando para ela o estatuto da ficcionalidade: a literatura explora aquilo que poderia ser. Eleva-se a capacidade do escritor de observar a experiência do outro e transformá-la em estética. Como um profissional da linguagem, o escritor contemporâneo é um alquimista, converte textos de caráter referencial e as experiências alheias em linguagem literária. É o que ele faz com os relatos de Dório: "Mais que criador, atuo como organizador e editor." (RUFFATO, 2014, p. 10).

Nessa relação Ruffato-Dório, há a delegação da voz, e o narrador deixa de ser aquele que colhe suas experiências na própria vivência. Como um periscópio, ele observa e perscruta mais do que vive. Se interpretarmos essa estratégia narrativa à luz da tese benjaminiana, é possível afirmar que ela atesta em definitivo a decadência da arte de narrar. No entanto, a narrativa ainda continua viva, porque em plena atividade, e o narrador modificou o seu papel, não mais o de conselheiro que narra o que viveu e, por isso, tem um ensinamento a dar, mas o tecedor de ruínas que não conta mais as experiências grandiosas e edificantes, porque elas não existem mais nem fornecem um repertório convincente nesse momento de crises das utopias. Ele prefere as memórias da dor, das experiências que não deram certo, das ruínas e dos restos. O narrador não tem conselhos a dar porque a experiência é a do trauma e ele parece não ensinar nada de grandioso, do mesmo modo que da 
guerra não se pode colher nenhuma verdade positiva ou edificante. Como afirma Theodor Adorno (1998, p. 26): "Escrever poesia depois de Auschwitz é um ato bárbaro." Da barbárie e do horror não se absorve nenhum ensinamento, a não ser evitá-los. O trauma é a sua linguagem, a aporia e o silenciamento tornam a experiência alijada de simbolização.

Numa perspectiva freudiana, Gagnebin (2009, p. 51) define o trauma como uma experiência de choque que "fere, separa, corta ao sujeito o acesso ao simbólico, em particular à linguagem". Em outras palavras, o trauma consiste nessa impossibilidade de atribuir um sentido, de dar uma resposta simbólica à experiência vivida, porque ela se fez demasiadamente dolorosa. Do trauma resulta a impossibilidade da narrativa, no sentido tradicional que resgata Benjamin (1987), de poder dar um conselho e ser ouvido. Porque a narrativa tradicional apresenta, também, esse aspecto fundamental: ter quem a escute e atribua a ela um sentido relevante, como o exemplo que constrói Benjamin (1987) em outro texto, escrito em 1933, "Experiência e pobreza": um vinhateiro conta uma história aos filhos no leito de morte, e os filhos escutam a história do pai. A narração do pai é levada em consideração, e os filhos aprendem a lição valiosa de que a riqueza estava no trabalho.

Partindo dessa perspectiva da recepção da narrativa para que ela seja significativa na comunicação das experiências, o que há de utópico nessa tarefa empreendida pelo narrador contemporâneo, então, de narrar as ruínas, os traumas, o indizível? Que sentidos podem ser atribuídos nestas tarefas: tanto na iniciativa de Dório de escrever suas memórias quanto na empreitada do escritor Ruffato em ler e reeditar essas histórias?

A iniciativa de Dório de ouvir e de narrar as ruínas, então, seria uma forma de viver o luto, de compreender profundamente o trauma e tentar dizê-lo, num exercício doloroso, mas também de resistência ao esquecimento. Trata-se de uma árdua tarefa, mas ouvir e narrar essas histórias do fracasso, da barbárie e da dor são exercícios de memória necessários para não deixar que elas voltem a acontecer. A história pode ser reescrita e dela se pode apreender um conhecimento valioso, por meio das testemunhas em suas diferentes variações: como aquela que vê (testis) ou como sobrevivente (supertis) e, principalmente, como a testemunha que ouve o insuportável relato e não vai embora. $\mathrm{O}$ escritor contemporâneo sabe que os conselhos perderam seu lugar, que nem ciência nem religião oferecem mais o inventário de verdades capazes de convencer e garantir a paz, a democracia, a 
liberdade. Mais que isso, esse narrador tem clareza de que as experiências são fornecidas por uma poderosa indústria cultural, que "alfabetiza pela imagem" (PELLEGRINI, 2008) e não pelo raciocínio lógico ou pela prática da reflexão. A técnica solapou a narrativa tradicional, mas, suplementando Benjamin (1987), é possível resistir. Em um mundo em que grupos privilegiados são detentores da voz, sobrepõem-se à voz dos subalternizados e operam o silenciamento, ouvir os vencidos e dar-lhes o poder de narrar seu lado dos fatos significa resistir e reinventar a arte de narrar.

Gagnebin (2009, p. 49) afirma que o texto de Benjamin deixou muitas questões não resolvidas - a morte da narrativa é uma delas —, e que os contemporâneos precisam se debruçar sobre elas para tentar propor novas saídas: "O pensamento de Benjamin se ateve a questões que ele não resolveu e que ainda são nossas, questões que sua irresolução, precisamente, torna urgentes. Talvez nossa tarefa consista em colocá-las de forma diferente." Como as personagens que Dório encontra nas viagens, Benjamin também está nessa condição de sem teto, sem pátria, errante que, por razões diversas, não tem uma experiência edificante a comunicar. São histórias de fracasso, de trauma e de dor: "Uma narração nas ruínas da narrativa, uma transmissão entre os cacos de uma tradição de migalhas." (GAGNEBIN, 2009, p. 53).

Tarefa dolorosa, mas necessária essa de narrar as ruínas, como no processo de luto, rememorar o passado para poder transformar o presente. Nas palavras de Gagnebin (2009), o narrador contemporâneo se porta como:

[...] esta personagem das grandes cidades modernas que recolhe os cacos, os restos, os detritos, movidos pela pobreza, certamente, mas também pelo desejo de não deixar nada se perder (Benjamin introduz aqui o conceito teológico de apokastasis, de recolecção de todas as almas no Paraíso). Esse narrador sucateiro [...] não tem por alvo recolher grandes feitos. Deve muito mais apanhar aquilo que é deixado de lado como algo que não tem significação, algo que parece não ter importância nem sentido, algo com que a história oficial não sabe o que fazer. [...] Essa tarefa paradoxal consiste, então, na transmissão do inenarrável, numa fidelidade ao passado e aos mortos, mesmo — principalmente — quando não conhecemos nem seu nome nem seu sentido. (GAGNEBIN, 2009, p. 53-54).

Tecedor de ruínas e não mais o conselheiro, eis a tarefa do narrador contemporâneo. A consciência desse narrador da inaptidão para dar conselhos, no 
sentido que defende Benjamin (1987), é reiterada no título do romance, formado pelo substantivo "flores", que remete a algo belo, e o adjetivo "artificiais", que denota cópia, engano, equívoco, algo não autêntico. Se tomarmos "flores" como metáfora da experiência narrada no romance, é possível depreender do vocábulo a significação de que há uma experiência comunicável, mas é uma experiência de outro, apenas observada e não colhida na vivência dos fatos. O vocábulo "artificiais" faz lembrar outro texto de Benjamin (1987), "A obra de arte na era de sua reprodutibilidade técnica". A caracterização de "artificiais" para qualificar a experiência narrada no romance ruffatiano, entendida como técnica, cópia, segundo a tese de Benjamin (1987), retira do objeto de arte o seu caráter humano, uma experiência fabricada, típica da cultura do olhar, da percepção humana sem um sentido profundo que descaracteriza a função social da arte que é a politização.

No entanto, se for possível promover uma politização por meio da arte, através da rememoração do trauma ou através da atividade terrível de ouvir o relato do sobrevivente, talvez, seja possível resgatar o sentido da narrativa no contexto da contemporaneidade. Como defende Gagnebin (2009), ao transformar o presente por meio da memória, então, a arte de narrar pode encontrar sua ressignificação e apontar para uma superação. A função do tecedor de ruínas é ser a testemunha, a terceira via de possibilidade, que, como no processo de luto, rememora o passado para não esquecer o presente. Mostrar as rasuras, o epílogo, os restos do processo falho da civilização humana no mundo contemporâneo (ROCHA, 2012), ocupando-se daqueles que a História oficial relegou e esqueceu, é tarefa cara ao narrador contemporâneo.

A essa altura da discussão, vale ressaltar a segunda instância da narrativa incorporada no romance: os significados da escrita para Dório. Observa-se que, mais uma vez, a experiência que Dório narra advém de seu papel de ouvinte das histórias alheias, em terras também alheias. Em todas as histórias, perpassa-se um tom de pessimismo. O não pertencimento, a solidão e o desamparo são os vetores constantes em todas as oito narrativas, seja pela guerra, seja pela violência institucional estabelecida em diferentes lugares do globo, seja pela miséria que afasta e insula o sujeito, alijando-o de uma vida plena. Segundo Gagnebin (2009), só quem não teve uma vida plena deseja narrar sua biografia. A escrita é uma forma de resolver as pendências da existência.

A narrativa de Dório pode ser interpretada nessa relação que estabelece Gagnebin (2009). Como um exercício terapêutico, Dório escreve sua experiência 
em um momento de recuperação de uma profunda depressão. Ele narra para dar sentido à existência e continuar vivo. Na carta que escreve a Ruffato, a personagem conta ao escritor que, na passagem do século, foi acometido por uma forte depressão e passou a se tratar com uma psicanalista. Viagens à terra alheia é o resultado do tratamento para vencer a depressão:

Fiquei afastado do trabalho durante todo o primeiro semestre de 2000. Depois, passei a viajar para o Rio uma vez por mês, para a doutora Regina acompanhar o tratamento. Ao longo das nossas conversas, acabei sentindo vontade de escrever as coisas que contava para ela. Entre março de 2002 e dezembro de 2009, aproveitei todas as horas vagas para pôr no papel as minhas memórias. (RUFFATO, 2014, p. 13-14).

As memórias evocadas por Dório estão impregnadas de um trauma pessoal e, diante disso, ele escreve para comunicar ao outro esse trauma e, por meio da enunciação, poder restabelecer as forças, vencer a dor e dar sentido à existência. $\mathrm{O}$ trauma de Dório é pessoal, está associado ao sentimento agudo de solidão:

Sentei de novo na poltrona e comecei a pensar. O que tinha feito da vida? Não casei, não tive filhos, nunca mais tinha falado com meu irmão e nem com minhas irmãs. Não tinha amigos para conversar comigo. Quanto mais se aproximava a meia-noite, mais angustiado ficava. Lembrei da minha mãe, que morreu quando eu tinha dezessete anos. Lembrei do meu pai, que na época ainda estava vivo mas que eu não procurava há anos. Lembrei das mulheres que cruzaram meu caminho. Parecia que naquela sala vazia estavam todos os meus fantasmas. (RUFFATO, 2014, p. 12-13).

Tudo que Dório narra é resultado dessa memória rasurada que o distanciamento temporal modifica e transforma. No entanto, é preciso ressaltar que Dório é apenas uma personagem inventada por Ruffato, e Primo Levi, citado no início do texto, é um ser humano real, sobrevivente de Auschwitz. Diferente do testemunho nesse ponto, a narrativa literária prescinde dessa preocupação em ser fiel ao real. O romance se ressente desse escrutínio ético que assombra Primo Levi. O romance tem, como afirma Marthe Robert (2007, p. 27), na sua organicidade, essa condição de sugerir o real sem ser obrigado a ser fiel à realidade: "O romance nunca é verdadeiro nem falso, fazendo apenas sugerir um ou outro, isto é, dispondo sempre exclusivamente da escolha entre duas maneiras de enganar, entre duas espécies de 
mentira que apostam desigualmente na credulidade". Ao citar Pirandello, Ruffato inverte essas instâncias, e o que aconteceu e o que poderia acontecer entrelaçam suas fronteiras. Ao ler as histórias de Flores artificiais, todas são plausíveis, críveis, retratando a situação desses seres errantes pelo globo terrestre, na mesma condição de tantos expatriados que o século XX fabricou: Levi e Benjamin são exemplares nesse sentido. Muitos outros poderiam ser citados.

Se tomarmos a emblemática frase de Adorno (2003) citada anteriormente, segundo a qual não é possível fazer poesia depois de Auschwitz, podemos observar que o crítico convoca os escritores a pensar a sociedade. Se, nas primeiras décadas do século XX, a arte conquistou a sua autonomia e a sobrevalorização do estético sobre o ético, como continuar se ocupando do estético, da estranheza da linguagem, em um mundo caótico que sucumbe em meio a horríveis guerras, duas mundiais para citar apenas as maiores, culminando na Shoah, e em outras horríveis barbáries que proliferaram durante o século XX por diferentes pontos do planeta? É por esse universo em ruínas, prenhe de conflitos e povoado de escombros, que transitam as personagens que Dório encontra, cujas experiências decide narrar no seu romance.

Como já foi referido anteriormente, Viagens à terra alheia compila oito histórias de personagens que Dório rememora e decide narrá-las. No próximo tópico, analisaremos apenas três delas, a fim de observar de que maneira se configuram a viagem e a narrativa na contemporaneidade.

\section{Transitando sobre escombros: a ressignificação da viagem na contemporanei- dade}

No texto sobre o narrador, Benjamin (1987) constrói duas metáforas: o camponês sedentário que conhece a fundo suas tradições e o marinheiro comerciante que colhe suas experiências das viagens que empreende e depois volta para sua terra. Em ambas as figuras, há um fator positivo na arte de narrar: o compartilhamento de experiências, das quais se pode retirar algum ensinamento. O narrador é, portanto, um conselheiro. Essa é uma característica imprescindível da narrativa tradicional. O conselho é a essência da narrativa, resultante de uma experiência vivida que produz a sabedoria. Se não se pode mais dar conselhos é porque a experiência se tornou incomunicável.

Tomando as metáforas dos narradores de Benjamin (1987), o viajante, ao retornar ao lar, sempre tem uma experiência a comunicar. Ulisses é o emblema 
mais bem realizado desse tipo de narrador, o aedo, que canta seus grandes feitos, a sabedoria que adquiriu ao se relacionar com outros povos e outras culturas. $\mathrm{Na}$ Odisseia, a narrativa de Ulisses torna-o um herói especial em relação ao homem comum, e é por isso que ele tem algo a narrar, e há, também, aqueles que desejam ouvir seus relatos. A experiência da viagem confere a ele a autoridade da voz narrativa. Essa era a característica distinta do herói épico: viver experiências grandiosas por meio das viagens e voltar para casa com autoridade para narrar as suas glórias e os seus grandes feitos. Ulisses, na terra dos Feácios, é esse narrador aedo que tem muitos conselhos e sabedoria para transmitir. Diferença fundamental entre Ulisses e o narrador contemporâneo é que o segundo transita por escombros, a retórica da guerra não é mais edificante: "A guerra é desmoralizante." (BENJAMIN, 1987, p. 199). Levi, Dório e Ruffato são emblemáticos desse tipo de narrador contemporâneo.

A primeira história, da qual se ocupa Dório, é a de Bobby, um inglês sem família nem qualquer outro tipo de vínculo com alguém no Brasil ou fora dele. Dório encontra Bobby quando ainda é um jovem estudante em Juiz de Fora e escuta dele os relatos de sua vida. Essa personagem nasce em 1929 e participa, direta ou indiretamente, dos eventos catastróficos do século XX. Há, na materialidade do texto ficcional, essa preocupação em trazer os acontecimentos do século XX como pano de fundo das histórias narradas.

Na infância, Bobby vive um tempo no Brasil com os pais. Mais tarde, de volta à Inglaterra, em 1940, ele perde o pai, que vai lutar na Segunda Guerra e nunca mais o reencontra, a mãe enlouquece e ele vai morar com os avós: "Ele havia se acostumado, após ouvir o silvo dos petardos caindo dos aviões, a se esgueirar pelas ruas de Southampton em busca de metralhas entre os escombros" (RUFFATO, 2014, p. 26). Os laços primários são os primeiros a desmoronar nesse processo de desterritorialização. Quando termina a faculdade de Química, vê-se perdido, sem ninguém no mundo, e, incapaz de formar uma vida social, ingressa no exército inglês para lutar no Quênia. A atividade que Bobby exerce nessa guerra é a de exterminar todas as pessoas feridas que encontrasse pelo caminho: "Sua missão era esquadrinhar o campo de batalha em busca de feridos e executá-los sem piedade." (RUFFATO, 2014, p. 28).

Depois dessa guerra, tornou-se mercenário em revoltas, na luta pela independência de outros países africanos. Para além desses "eflúvios revolucionários", ele vai para os campos de batalha porque não tem mais para 
onde ir. Em 1964, de volta à Inglaterra, Bobby sente o desejo de reconstruir sua vida e retorna ao Brasil. O país está vivendo o início do processo de ditadura, mas Bobby é alheio a tudo isso.

"O país respirava dias agitados, greves, manifestações políticas inflamavam as avenidas e as páginas dos jornais, mas ele mantinhase ignorante das marchas e contramarchas. Gostava, nos fins de semana, de assistir no Pacaembu os jogos de time do Santos" (RUFFATO, 2014, p. 55-56).

Esse resumo da história de Bobby simboliza o tipo de experiência que o romance decide contar, são seres anônimos, medíocres, nem anjos nem demônios, mas, em todos os casos, perpassados pela violência, pelo desamparo e pelos deslocamentos.

Até parece que a história de Bobby funciona como um prelúdio do que a vida de Dório vai se tornar no futuro: sem família, sem pátria, sem fé, sozinho e solitário. O que Dório decide narrar são os encontros de pessoas que, como ele, estão sozinhas no mundo. A solidão seria uma forma de autoidentificação. Dório, no romance, constitui-se pela narrativa do outro, pela alteridade, num jogo de espelhamentos, em que o que é dito sobre o outro não consiste numa escolha aleatória, mas reflete os traumas individuais. É necessário observar que as histórias narradas não são escritas tão logo elas acontecem, mas são resgatadas pela memória. No trecho que segue, o narrador incorpora essas preocupações ao dizer a história do outro:

Este é um arremedo de biografia, construída como pontes pênseis sobre abismos. Tudo que sei sobre Bobby, lembranças de lembranças, foi-me relatado de maneira caótica, com largos lapsos e imensas contradições. E costuro esses fragmentos, ouvidos há mais de trinta anos, com uma linha que não distingue mais memória e imaginação. (RUFFATO, 2014, p. 24).

Nesse ponto, é possível desconfiar da narrativa. Quando a memória resgata um fato acontecido, ela o faz por meio de uma subjetividade, que pode estar influenciada pelas experiências do narrador, instaurando uma impossibilidade de dizer o vivido de forma objetiva. Quando a memória falha, é o momento de fazer a imaginação operar para preencher as lacunas. Essas lacunas são preenchidas a partir de marcas de uma subjetividade. No caso de Dório Finetto, sua subjetividade está marcada pelo sentimento de solidão e depressão, e é a partir desse olhar distópico 
que a narrativa se constrói. Há uma relação de espelhamento entre a história de Dório e as histórias das personagens que ele encontra. Pelo menos essa premissa é observável na maioria das histórias narradas. O narrador abdica da centralidade de si, enquanto protagonista do relato, para se portar como ouvinte da história do outro. O narrador se omite da autoridade de narrar sua própria vida. Parece que a própria história se torna vazia de sentidos e significados, como resultado da falência da capacidade de simbolizar o trauma.

Em Ruffato, o narrador não tem uma experiência vivida, autêntica, para contar ao leitor, exceto a de ser ouvinte da história alheia que, por sua vez, não apresenta grandes feitos. Ao contrário, são todas personagens desprovidas de grandes enredos, do qual retirar algum ensinamento, para lembrar aqui o texto de Benjamin (1987) sobre a falência do narrador na contemporaneidade. São pessoas ordinárias com suas vidas ordinárias, sem experiências edificantes e sem lugar no mundo, exatamente por não se encaixarem em nenhuma lógica de sociabilidade ou porque são incapazes de dar respostas positivas ou altruístas, em um mundo que se apresenta inóspito e sem saída. Não há saber profundo para transmitir quando para as principais questões contemporâneas ainda não há respostas, em que o passado recente nem mesmo foi compreendido. Essa decadência da transmissão de um saber por meio da narrativa é transformada na opção formal do narradortestemunha que se exime de ser o protagonista das ações para ouvir a história do outro.

Os lugares ambicionados por essas personagens, como Bobby, por exemplo, são os bares, os hotéis, as infindáveis viagens. "Preferia a solidão dos bares e botequins das redondezas da fábrica, onde todos os dias bebia duas cachaças e três garrafas de cerveja e mastigava tira-gostos, antes de voltar para casa." (RUFFATO, 2014, p. 35). Todos os encontros de Dório se dão nesses não lugares (AUGÉ, 1994). Por outro lado, essa condição de errante e solitário não é bem resolvida por Dório. Frequentemente, há a enunciação da vontade de ser o outro: o casado, que tem filhos, endereço fixo, família, vínculos afetivos e sociais, cuja ausência transtorna a existência da personagem, como pressuposto também da ausência de uma vida feliz: "Então, Bobby desejou também tornar-se urgente homem sério, pai de família, cidadão respeitável, e, envolto em repentina convicção, falou que achavase prestes a deixar a Inglaterra, talvez em definitivo, rumo ao Brasil." (RUFFATO, 2014, p. 35). Como é possível perceber, nesses fragmentos, Bobby não é uma personagem de objetivos fixos e estáveis. A incerteza e a mobilidade dos valores 
e das perspectivas são inerentes a essas personagens. Em outro trecho, o desejo de fixar-se é refutado: "Sentiu-se só, incapaz de cumprir um papel na sociedade, constituir família, filiar-se a algum clube, morrer enfastiado nos estreitos limites da ilha." (RUFFATO, 2014, p. 27).

No final da vida, Bobby caminha de bar em bar, pelas ruas de Juiz de Fora, com sua mala de venenos de matar ratos, não consegue construir nenhum vínculo duradouro em sua vida. Quando morre, é enterrado numa cova rasa e perde sua identidade para sempre, salvo pelo relato de Dório. Outro aspecto que é interessante notar da empreitada do narrador de ruínas: dar voz aos excluídos, aos anônimos. Empreitada essa muito diferente daquela realizada por Ulisses e distante do significado que exerce a narrativa para consolidar um tipo de valor no mundo antigo. Como o norte-americano evocado no início desta discussão, Bobby também é um ex-combatente de guerra, e essa violência transforma-o num sujeito esvaziado de sentimentos profundos, incapaz de socializar e de transmitir um ensinamento.

Em quase todas as histórias, Dório demonstra a capacidade de empreender uma aproximação com pessoas também carentes de vínculos, pessoas em trânsito tanto físico quanto identitário. Em Ruffato, o trânsito no espaço geográfico está ligado a uma configuração subjetiva desse espaço, característico de uma identidade também instável e à procura de traços que a identifiquem. Na quarta história, intitulada "Uma tarde em Havana", Dório encontra-se com uma mulher chamada Nádia. Mais uma vez, coadunam-se os traços da mobilidade. Nádia está presa numa Cuba dos anos 1980. Ela representa aqueles que não podem buscar um outro lugar. Para fugir da violência e da miséria, ela se agarra a qualquer vestígio de possibilidade de fuga:

$\mathrm{Eu}$ atentava curioso para uma coleção de moedas raras, quando Nádia perguntou, de chofre, Quer casar comigo? Respondi jocoso... como é mesmo o nome dele? De quem? De seu pretendente brasileiro? Ofendida, afastou-se. Cabisbaixa, conservou-se ao largo, me aguardando. (RUFFATO, 2014, p. 97).

Esse pedido súbito de casamento traduz o desespero de Nádia para, como um náufrago, agarrar-se a qualquer aceno de oportunidade de partir para outro lugar.

Essa história tem como pano de fundo a cidade de Havana, aproximadamente, no ano de 1980, momento de enrijecimento da ditadura empreendida pelo governo 
de Fidel Castro. A repressão e a violência institucionais estão presentes nesse capítulo como uma força panóptica, que cerceia e silencia os sujeitos. Antes do encontro com Nádia, Dório passeia pelas ruas de Havana e passa por um homem manuseando uma enxada. Esse homem lhe pede sua camisa. O tom desse encontro é de insegurança, o homem teme, a todo o momento, uma vigilância anônima, mas atuante, que o narrador sugere, sem escancarar para o leitor. Nádia também teme ser flagrada e, em vários momentos, suas ações são reprimidas por essa força controladora que alija os sujeitos de uma vida plena. Se o liberalismo e as propostas iluministas não fornecem mais um repertório de saberes validado socialmente como justo, próspero e feliz, tampouco o socialismo toma seu lugar.

Dório descobrirá com Nádia o submundo dessa cidade, e a miséria, o desamparo e a violência são as marcas recorrentes. Nas incursões turísticas, Nádia conduz Dório a um cubículo e lhe oferece o prazer sexual como moeda de troca, que ele recusa de forma enérgica, acentuando, ainda mais, a situação de degradação humana e de desespero da personagem. Dório sai rapidamente, e Nádia fica nua, em cima de uma cama fétida, num ambiente inabitável e hostil. Ela representa os impossibilitados de fugir, de procurar uma "paragem aprazível”, para quem nem mesmo a errância se coloca como possibilidade de resistência contra a violência e o desamparo. À Nádia só restou permanecer na miséria e na marginalidade. Esse episódio faz com que o narrador pense a respeito de si e se conscientize daquilo que lhe falta: a ausência de vínculos, a condição de não pertencimento e de errante solitário. Ao final desse capítulo, Dório reflete sobre sua própria vida:

Quando, sem fôlego, voltei à tona, era apenas destroços, um homem que avançava célere para os sessenta anos e sabia que não ocupava o pensamento de nenhuma pessoa no mundo. Que quando retornasse para casa não haveria ninguém me aguardando, nem mulher, nem filhos, nem parentes, nem sequer um gato ou um cachorro. Que caso morresse ali, naquele momento, ninguém lamentaria minha ausência. E que, irredutível, a velhice afagava o tempo malbaratado. O garçom depositou o mojito no tampo, agradeci, bebi um gole com sofreguidão, e pensei que necessitava urgente tomar um banho, um longo banho para me livrar daquela crosta grossa que se acumulava sobre minha pele. (RUFFATO, 2014, p. 100).

O episódio com Nádia desencadeia uma série de reflexões que faz com que Dório pense a respeito da sua existência e se conscientize do fato de ele não pertencer a nenhum lugar, deslocado no sentido espacial e no sentido identitário. O 
que restou das viagens que ele empreendeu durante boa parte de sua vida? Apenas essa condição de ruínas, destroços, culminando no final da narrativa, quando volta para casa e não há de fato nem família, nem mulher, nem filhos, nem sequer um animal de estimação:

Tenho conhecidos, colegas, correspondentes, não amigos, aquelas pessoas imprescindíveis, que contamos quando carecemos dividir algo importante ou sem importância, aquelas pessoas com quem, ainda que nos ausentemos por anos, conseguimos reatar conversas como se tivéssemos estado juntos na noite anterior. Que nos compreenda pelo olhar, pela postura, pelo tom de voz... Não pertenço a lugar nenhum, sou, sempre fui um estranho, um estrangeiro... Não me entreguei à vida — ela me largou num parque abandonado. (RUFFATO, 2014, p. 140).

Ao voltar para casa, Dório não tem ninguém a quem contar sua narrativa. Diferentemente de Ulisses, ele só carrega consigo destroços, experiências traumáticas e desmoralizantes, um narrador sucateiro que se ocupa daquilo que desmoronou. Além disso, tomando Ulisses como parâmetro para compreender esse narrador contemporâneo, é possível observar que ele não sabe por que viaja, nem para onde viaja. Esse deslocamento espacial promove também um deslocamento subjetivo, em que o eu questiona sua própria identidade. Ulisses prescinde de questionamentos identitários. O homem contemporâneo transita pela cidade moderna, palco dessas andanças e deambulações esvaziadas de sentido, para entender quem é, para encontrar-se e encontrar o outro. A falência da retórica da viagem é evidenciada pela ausência de ponto de partida e chegada, cabendo aqui a metáfora da deriva ou do nomadismo para compreender os sentidos da solidão na narrativa contemporânea. Sem grandes utopias, resta à voz narrativa o relato dos destroços, dos escombros, para que, como propõe Gagnebin (2009), seja possível rememorar o passado e não esquecer o presente.

\section{Considerações finais}

Nesta discussão, buscou-se compreender quais os sentidos que a errância e a narrativa assumiram no romance Flores artificiais, do escritor Luiz Ruffato. À luz de teóricos como Benjamin (1987) e Gagnebin (2009), que discutem a configuração do narrador, buscou-se, primeiramente, identificar como as fronteiras do real e do ficcional se embaralham no romance lido, a fim de dar novas respostas à 
problemática da arte de narrar na contemporaneidade. Ruffato explora a autoficção e o narrador-testemunha, aquele que não mais narra os seus feitos e, sim, o ouvinte que não tem uma sabedoria para contar, contudo pode conduzir o leitor por um universo de ruínas e traumas, a fim de, quem sabe, como defende Gagnebin (2009), esboçar novas possibilidades de rememorar o passado e lembrar o presente. Em um segundo momento, propôs-se a pensar o entrelaçamento dos temas da viagem e da narrativa, observando que o romance esboça, por meio de inúmeras viagens do narrador-personagem, um mundo em ruínas, e que a experiência que ele colhe nessas andanças, diferentemente de Ulisses, é a do trauma, seja individual ou coletivo, seja devido às guerras que se multiplicaram no breve século XX, seja devido à violência e à repressão empreendidas pelas ditaduras nas Américas, seja pela miséria e pela segregação a que milhares de pessoas estão expostas todos os dias, espalhadas pelo globo terrestre.

O romance ruffatiano, para dar conta dessa volatilidade desses múltiplos espaços, sobretudo o espaço das grandes cidades, não poderia se constituir pelas características tradicionais de causalidade e de linearidade. Essa recusa do discurso do romance tradicional, que não questionava os lugares comuns da autonomia do literário, da voz e do foco narrativos, da centralidade da personagem protagonista, da linearidade temporal e da descrição do espaço, se manifesta num amálgama de características que constitui uma escrita patchwork (CANEVACCI, 2004), feita de restos dos mais variados textos e intersemioses, que o leitor precisa ir alinhavando/ costurando para formar os sentidos do enredo. Uma escrita Frankenstein, feita de fragmentos e imantada de signos diversos, impõe um questionamento sobre a constituição da própria narrativa na contemporaneidade, como aquela que não mais dá uma resposta, uma saída positiva para os problemas do mundo pós-guerra e pós-trauma, com os quais a contemporaneidade precisa lidar.

O desenraizamento em relação a um lugar pode provocar a reterritorialização, processo de identificação com a sociabilidade do novo lugar, como aconteceu com muitos intelectuais ao longo do século XX, principalmente a partir da Segunda Guerra Mundial. Devido às questões de violência institucional exercida de várias formas ao longo desse século, resultando na perseguição de grupos minoritários - como na Shoah, ou na colonização de países africanos por países europeus, ou nas inúmeras ditaduras latino-americanas —, exilados, expatriados de muitas partes do globo buscam, em países mais democráticos, capitalistas e liberais, uma nova territorialização. Entretanto, ao lado dessa reterritorialização, há também a 
ausência dessa identificação com o outro lugar, tampouco com o lugar de origem, criando um sujeito incapaz de ancorar-se em algum lugar. Essa parece ser a situação explorada por Luiz Ruffato em seus romances.

\title{
Fighting with Words Among Ruins: Narrative and Wandering in Luiz Ruffato's Flores Artificiais
}

\begin{abstract}
The contemporary Brazilian narrative has problematized the relation between subject and space in different ways, giving emphasis to the issue of traffic in the great urban centers and the numerous trips made by characters. These "non-places" (AUGÉ, 1994) have their relevance guaranteed through the construction of characters who are passersby, wanderers, travelers, tourists, migrants and immigrants, who are unable to settle down anywhere, nor establish relations of intimacy and belonging to the places through which they travel. In the light of these findings, we will discuss the intricacy of two themes, wandering and narrative, in Luiz Ruffato's novel Flores Artificiais, published in 2014, since not only the aforementioned relation between subject and space is questioned, but also the boundaries of narrative in the context of contemporaneity.
\end{abstract}

Keywords: Witness. Travel. Narrative.

\section{Referências}

ADORNO, T. Crítica cultural e sociedade. In: Adorno, T. Prismas. Tradução de A. Wernet e Jorge Almeida. São Paulo: Ática, 1998. p. 7-27.

AUGÉ, M. Não-lugares: introdução a uma antropologia da supermodernidade. Tradução de Sérgio Paulo Rouanet. São Paulo: Papirus, 1994.

BENJAMIN, W. Magia e técnica, arte e política: ensaios sobre Literatura e História da Cultura. São Paulo: Brasiliense, 1987.

CANEVACCI, M. A cidade polifônica. São Paulo: Studio Nobel, 2004.

DALCASTAGNÈ, R. In: Orelhas do livro. HARRISON, M. I. Uma cidade em camadas: ensaios sobre o romance Eles eram muitos cavalos, de Luiz Ruffato. São Paulo: Horizonte, 2007. 
DUARTE, K. B. Autoficção. In: BERND, Z. Dicionário das mobilidades culturais: percursos americanos. Porto Alegre: Literalis, 2010. p 27-45.

GAGNEBIN, J. M. Lembrar, escrever, esquecer. São Paulo: Editora 34, 2009.

GOODY, J. Da oralidade à escrita: reflexões antropológicas sobre o ato de narrar. In: MORETTI, F. (Org.). O romance: a cultura do romance. São Paulo: Cosac Naify, 2009. p. 35-67.

HARRISON, M. I. Uma cidade em camadas: ensaios sobre o romance Eles eram muitos cavalos, de Luiz Ruffato. São Paulo: Horizonte, 2007.

HOMERO. Odisséia. São Paulo: Abril, 1978.

LEVI, P. É isto um homem? Tradução de Luigi Del Re. Rio de Janeiro: Rocco, 1988.

PELLEGRINI, T. Despropósitos: estudos de ficção brasileira contemporânea. São Paulo: Annablume; FAPESP, 2008.

ROBERT, M. Romance das origens, origens do romance. São Paulo: Cosac Naify, 2007.

ROCHA, R. C. As formas do real: a representação da cidade em Eles eram muitos cavalos. Estudos de Literatura Brasileira Contemporânea, Brasília, n. 30, p. 119-127, jul.-dez. 2012.

RUFFATO, L. Eles eram muitos cavalos. São Paulo: Boitempo, 2001.

RUFFATO, L. Flores artificiais. São Paulo: Companhia da Letras, 2014. 